\title{
LA CÓLERA DE AQUILES: UN TEXTO PRODUCTO DEL LECTOR
}

Por

ROBERT C. SPIRES

University of Kansas

La publicación de Recuento por Luis Goytisolo en 1973 marcó el principio de todo un movimiento novelístico en España. Este movimiento, que va mucho más allá de las innovaciones técnicas y lingüísticas de la Nueva Novela de los años 60, estriba en una novela que se refiere a sí misma; una novela, en fin, que trata de su propia escritura artística. En 1979 el propio Luis añadió una dimensión significativa a este tipo de novela autorreferencial: en La cólera de Aquiles ${ }^{1}$ pone de relieve no sólo el proceso creador de escribir, sino y sobre todo el de leer. Pues citando las mismas palabras de la narradora: "El valor del texto, en lo que a las obras de ficción se refiere, es cosa de la que ya se ocupa--o debiera ocuparse--la critica literaria... No el texto, sino la lectura del texto. No el contenido en sí del mensaje, sino la lectura en sí de ese mensaje"(p. 297). De hecho, La cólera de Aquiles nos fuerza a ocuparnos del fenómeno de la lectura mediante el recurso de respuestas escritas a unas cartas y a una novela intercalada. De modo que, dentro de la novela, el acto de escribir no es sino la expresión gráfica de una lectura, igual que La cólera de Aquiles representa por parte de Luis Goytisolo la expresión gráfica de su lectura de otros textos-su respuesta a ellos. Y puesto que la respuesta, aunque parecida, siempre será distinta del texto anterior, la relación lecturaescritura consta de una estructura de diferencias. Partiendo así de la relación paralela y contrapuesta de los fenómenos lectura-escritura, Luis Goytisolo desarrolla en su novela un sistema de diferencias que no es sino reflejo dramático de la laguna que existe siempre entre el signo y lo señalado.

La base anecdótica que gira alrededor del eje estructural escritura-lectura trata de una narradora en primera persona, una lesbiana llamada Matilde Moret, quien narra los problemas amorosos ocasionados por un tal Roberto que pretende robarle a Matilde su amada, Camila. Gran parte de su narración versa sobre la lectura de unas cartas que Roberto y Camila se escriben a sabiendas, según Matilde, de que ella las leerá. En un momento determinado,

${ }^{1}$ La cólera de Aquiles (Barcelona: Seix Barral, 1979) Las citas son de esta edición y se indicará la página entre paréntesis. 
Matilde interrumpe su narración para volver a leer una novela que publicó hace años bajo el seudónimo de Claudio Mendoza, y nos la presenta textualmente. Los comentarios que siguen a la novela intercalada tienen el propósito de corregir lo que Matilde considera la lectura errónea por parte del que fue su destinatario secreto, su primo Raúl. De suerte que estos comentarios representan la respuesta de ella a una lect ura hecha por él, de una obra escrita por ella. Es más, los comentarios de ella no van dirigidos a Raúl sino todavía a otro destinatario secreto. Así cada respuesta es un acto comunicativo que, al intentar corregir el anterior, nos aleja más del punto de origen, haciendo resaltar con cada paso de alejamiento el sistema de diferencias. Dirigiendo mi atención ahora a las cartas, a la novela intercalada y por fin al concepto de los destinatarios, intentaré demostrar cómo las diferencias resultantes de cada paso de alejamiento son inherentes no sólo al lenguaje en general, sino a la existencia humana.

Las cartas escritas por Roberto y Camila y leídas impúdicamente por Matilde sirven para iniciar el sistema de diferencias basado en la relación escritura-lectura. El propósito por parte de Matilde es medir la pasión entre los amantes y arreglárselas a fin de intensificarla y a la vez evitar su cumplimiento. Y para complicar el juego, empieza a escribir sus propias notas íntimas en forma de diario con un tono acorde con el último expresado por Roberto, y a dejarlas donde Camila las pueda encontrar y leer. Matilde misma describe estas notas como "respuestas a la respuesta de una respuesta"(p. 42). La repetición de la palabra "respuesta" realza la diferencia entre un texto determinado y otro tex to creado por una lectura interpretativa del primero. El primero queda suplantado, casi borrado, conforme una lectura responde a otra formando una cadena potencialmente infinita de diferencias.

Al comentar directamente las cartas, Matilde nos ofrece varios ejemplos concretos de la estructura de diferencias puesta de manifiesto por la lectura. Tal vez el ejemplo que se destaca más trata de sus esfuerzos por aclarar ciertas palabras y frases de las cartas dirigidas a ella. Así, explica del modo siguiente una referencia a una clase de ballena:

Así, aquella frase relativa al cachalote, cuyo alcance, pese a escapárseme de entrada, no dejó por ello de golpearme con dureza, confieso, ahora que puedo hacerlo. Tú no sabes lo que es encontrarse con un cachalote en la cama, escribió literalmente Camila en una de esas cartas que dejaba por la casa un tiempo prudencial antes de hacérsela llegar a Roberto. Tardé lo mío, ésta es la verdad, en caer en la cuenta de que, a lo que realmente estaba aludiendo era a mi fogosidad amorosa, una peculiar forma de ferocidad que, para bien o para mal, no puedo menos que reconocer como muy mía. Hubiera quedado mejor poniendo una pantera en lugar de cachalote, es cierto (pp. 308-309). 
La interpretación ofrecida por Matilde, aunque no definitivamente errónea, es, a todas luces, forzada. Es más, nos hace dudar de la veracidad de discursos anteriores donde Matilde se refirió a su "perfecta forma física" (p. 31) o se describió como "alta, esbelta, elegante"(p.60), y otros de la misma índole. Es díficil no ver en la imagen de un "cachalote en la cama" a una mujer todo lo contrario de "alta, esbelta, elegante". Y respecto a la fogosidad amorosa, tal como Matilde misma observa, "hubiera quedado mejor poniendo una pantera en lugar de un cachalote, es cierto". De modo que el humor de esta interpretación proclama bien a las claras como la relación escritura-lectura sirve para descubrir la estructura de diferencias inherente al lenguaje humano. Además, el mismo humor señala otra estructura de diferencias que suele pasar inadvertida. En el juego que es la ficción, normalmente se acepta a pies juntillas lo que se narra-la llamada "suspension of disbelief"-a menos que otra narración lo desdiga. Pero sólo al indicar en este caso que todo se basa en la lectura de otro texto-hay que notar que ni aun se presenta este otro texto de las cartas-inmediatamente la narración pierde su ilusión de autoridad y juzgamos los comentarios de la narradora con el mismo escepticismo con que juzgamos cualquier interpretación. O sea, el humor nos aleja del mundo ficticio lo justo para que podamos darnos cuenta de que cada escritura no es sino una respuesta a otra escritura, y por eso cualquier sentido de origen y centro de autoridad infalible es ilusorio. El desenmascarar la ilusión de la infalibilidad de la narración es el primer paso hacia un enfrentamiento con la estructura de diferencias que forma la esencia de toda obra de ficción.

Si una novela tradicional intenta esconder su estructura de diferencias, la novela intercalada,"El Edicto de Milán", sirve para hacerla nítida. Al presentar el texto de su novela, Matilde, tras dejarnos una nota biográfica con el seudónimo Claudio Mendoza como autor, desaparece como narradora. $Y$ puesto que la voz narrativa de la novela intercalada queda anónima y la acción es focalizada por los ojos de la protagonista Lucía, durante sus casi cien pá ginas nos olvida mos no sólo del supuesto autor Claudio, sino incluso de su supuesta creadora Matilde, y del verdadero creador de todo, Luis Goytisolo. Pese a ser una ficción dentro de otra ficción, la ilusión de realidad es intensificada. El desenmascaramiento de la ilusión ocurre cuando Matilde recobra la narración y se pone a comentar el texto intercalado. Si antes Lucía, la protagonista de "El Edicto de Milán", nos capturó con su ilusión de realidad, ya es Matilde quien lo logra al poner a la vista la ficción de Lucía. Mas de repente Matilde desenmascará la ilusión de su propia realidad al hablar de ciertas claves que dejó en "El Edicto de Milán” para que el crítico avezado, citando sus palabras, "pueda llegar a la sagaz conclusión de que Claudio Mendoza es una mujer y, por añadidura, lesbiana. De ahí que 
cualquier hipotético lector de las presentes líneas pueda concluir a su vez, no menos sagazmente y en virtud del mismo juego de compensaciones, en que mi nombre, Matilde Moret, encubre un varón; cosa, por otra parte, acaso más cierta de lo que a primera vista pueda suponerse" (p. 202). Al decir "mi nombre, Matilde Moret, encubre un varón", la narrad ora nos aleja del mundo ficticio y nosotros nos damos cuenta del juego manipulado por Luis Goytisolo. En efecto, ya alejados podemos reconstsruir el juego de identidad sexual notando que el hombre real, Luis, crea una mujer ficticia, Matilde, quien finge crear un hombre ficticio, Claudio, quien finge crear por su parte una muchacha ficticia, Lucía. Pero tal reconstrucción desde fuera tampoco explica cumplidamente la novela. La cólera de Aquiles no es sólo el juego descubierto como juego, sino también nuestra experiencia estética creada por el juego-la ilusión de realidad. O sea, Lucía, la creación ficticia más alejada de la realidad, es, de cara a la experiencia estética, la más real de todas estas figuras; mas separándonos de la experiencia estética, sabemos que sólo Luis Goytisolo es real. En fin, una novela autorreferencial, al llamar la atención a su artificio, pone sous rature - tacha con equis - la misma ilusión que la define como ficción; aleja al lector del mundo ilusorio y lo pone en contacto con el mundo real. Pero tachar con equis no es borrar totalmente; al contrario, nos permite seguir viendo lo tachado al lado mismo de lo que lo suplanta. Lo tachado, aunque defectuoso, es necesario. En otras palabras, una novela autorreferencial nos permite experimentar la ilusión y a la vez reconocerla como ilusión; nos sugiere que, no obstante ser un juego de fantasías, la ficción es tal vez el mejor medio que tenemos para representar la realidad. En resumidas cuentas, la obra de ficción no es sino otro signo lingüístico que se suele confundir con la realidad; al verla tachada con equis (el efecto logrado mediante una novela autorreferencial), nos damos cuenta de que señala la ausencia y no la presencia de realidad. Y el reconocimiento de la ausencia es lo que explica el eje estructural de esta novela, y tal vez la vigencia de la literatura en general. Cada obra no es sino respuesta a otra obra, eslabón en una cadena de diferencias en búsqueda inútil, pero a la vez dinámica, de la fusión absoluta entre el lenguaje y la realidad.

La búsqueda por fin lleva a Matilde a una relectura de una obra anterior a la literatura escrita, la historia de Aquiles. Quiere ver en ella un referente a la angustia que siente. La madre de Aquiles, nos recuerda, so pretexto de salvarle, raptó a Aquiles, que estaba bajo la tutela de Quirón, y lo metió en una especie de convento de monjas vestido de niña. Matilde quiere ver en este rapto una desviación impuesta desde fuera y por eso Aquiles es, para ella: "aquel que no ha logrado superar la creencia de haber sido víctima, en sus primeros años, de la traición y el abandono, de haber sido sometido a las reglas de un mundo que no era el suyo, constreñido a simular una manera de 
ser que nada tiene en común con la que le es propia"(p. 274). Así alejándose a la primera infancia del ser humano logra vislumbrar una cadena de experiencias que la une no sólo con Aquiles sino con el destinatario de su propio discurso: "Yo escribo para quien sea consciente de que, en definitiva, en mayor o menor grado, todos hemos sido víctimas de la dicotomía a la que estoy refiriénd ome, de que a todos se nos ha robado algo de nosotros mismos" (p. 274). La dicotomía no parece ser sino la estela dejada en toda escritura por este algo robado cuya identidad concreta queda más allá de la conciencia de la víctima. Y no teniendo identidad concreta, cada víctima-sea emisor o receptor-lo experimentará de una manera única. Aunque el punto de origen se ha perdido y sólo sentimos su estela, la búsqueda de su definición sigue a lo largo de la existencia humana conforme una lectura da lugar a otra, en un proceso eterno de alejamiento. De forma que la búsqueda inútil del origen, de una fusión absoluta entre el lenguaje y la realidad, a la vez que crea frustración y cólera, es una fuerza dinámica y creadora. Pero para mantener en marcha este dinamismo, hacen falta lectores, cada uno de los cuales forma otro eslabón en la cadena de la existencia humana.

Así como hay una cadena formada por el proceso de un tex to dando lugar a una respuesta, y de ahí a otra, etc., hay otra formada por los destinatarios. $\mathrm{O}$ sea, cada respuesta va dirigida a un lector más alejado del destinatario original, creando un proceso de alejamiento que lleva inexorablemente al lector fuera del texto. La narradora misma explica el enlace entre el destinatario, dentro del texto, y el lector, fuera de él: “hay siempre, consciente o inconscientemente, un destinatario secreto por parte del autor, respecto al cual, consciente o inconscientemente, tiende a identificarse cada lector" ( $p$. 237). Así a fín de que la comunicación no falle, el lector de La cólera de Aquiles ha de intentar una identificación con un destinatario dentro del texto cuya identidad concreta nunca se revela. De ahí que quede subrayada la imposibilidad de cruzar la laguna de diferencias que separa al lector, fuera del texto, del destinatario, dentro de él. Como resultado de esto, cada lector crea su propio texto al leer, un texto cuya identidad con el anterior siempre será definida por la diferencia entre los dos. En fin, si bien es cierto que cada texto es producido por el acto de ser leído, no cabe duda de que La cólera de Aquiles es, en toda la extensión de la palabra, un texto producto del lector. 
